\title{
Engineers and conservation: two centuries and no progress?
}

Mike Chrimes MBE, BA, MLS

Institution of Civil Engineers, London, UK (m.chrimes@ntlworld.com)

Early engineers drew heavily for exemplars on the achievements of the past. Telford's employment as a county surveyor involved restoration of existing works. However, engineers were often accused of despoiling the existing environment; Telford himself was involved in the destruction of the precinct of St Katharine's by the Tower of London, and there are abundant examples of railways showing scant concern for the heritage through which they passed. In contrast, engineers like Benjamin Baker and Francis Fox used their engineering skills to extend the life of threatened structures. There is frequent debate between those seeking to improve the existing infrastructure and those who want such improvements to take account of the historic engineering heritage. Recent examples include the strengthening of Brunel's Thames tunnel and Network Rail's improvement works in Manchester. Heritage successes are often based on a few committed individuals using their engineering knowledge to mount successful campaigns. Despite more powerful analytical tools and ever-improving monitoring technology, structures like the internationally significant Union Suspension Bridge are under threat. Some may argue it all comes down to money, but is it in part a result of engineers' education and their lack of knowledge of their own heritage and sense of place?

\section{Introduction}

Today's practising engineers will inevitably spend much of their time dealing with existing structures and a man-made environment. UK Construction statistics (ONS, 2016) suggest that repair and maintenance is approximately one-third of the output over the last 5 years, which is probably an underestimate, as 'new works' such as Crossrail and the impending Thames Tideway involve continuous interface with existing buildings and infrastructure. Even with a projected designed life of 120 years, major works on High Speed 2 (HS2) will have regular maintenance regimes and well-funded clients such as the Bridge House Trust (City of London) have 50 -year maintenance programmes for the structures in their ownership. Experience suggests they may well become victims of their success, requiring modification within decades.

Before civil engineers emerged as a profession in the mideighteenth century, centuries of experience with infrastructure such as flood and drainage schemes, bridges and navigation works had demonstrated the need for properly funded maintenance regimes, management boards and expert labour (Brooks et al., 1994; Hallom, 1965; Skempton et al., 2002, 2008, 2014; Van de Ven, 2004).

Mediaeval cathedrals, whose construction campaigns sometimes extended over centuries, generally retained a masons' yard and expected to call on master masons or the like if structural problems emerged (Addis, 2007; Harvey, 1971) As an example, the Freiburg Muensterbauhuette (Figure 1) has existed since 1200 (Kalchthaler et al., 2014). In the UK, Durham Cathedral claims to have had a masons' yard since its foundation and Canterbury Cathedral and seven other cathedrals collaborate to maintain the training of masons to this day. This embedded societal expertise was relatively easy to maintain when using traditional materials, but increasing use of fabricated materials - metals, concretes and plastics - and increasingly sophisticated analytical methods has increased the likelihood of generational memory loss and lack of knowledge and understanding of older structures.

Traditional repositories such as the Institution of Civil Engineers (ICE) Library and archives have an important role to play in providing engineers with information on structures and engineering of the past (Chrimes, 1989, 2001). However, over the last three decades, the numerical modelling tools available to engineers have become more powerful, and more recently, sensors and monitoring devices have shown rapid developments, all enabling potentially better engineering decision-making (Mair et al., 2016; Soga et al., 2015; Standing et al., 2015). Increasing industry adoption of Building information modelling should mean more comprehensive data capture relating to the design, construction and maintenance of structures and thus better informed maintenance and renewal decisions by engineers (ICE, 2016).

However, better analytical tools will not necessarily mean better conservation practice. The longevity of the data now being compiled is questioned when so much of the information technology industry is driven by the relatively short-term horizons of the financial sector. Understanding of the value of engineering heritage will not necessarily be improved, and financial constraints may lead to the adoption of short-term solutions rather than conservation-based designs and the storage of data for future maintenance. While the engineering profession has long shown interest in and respect for its heritage and the broader heritage in the built environment, it also has frequently shown scant respect for the work of past generations in the pursuit of current 


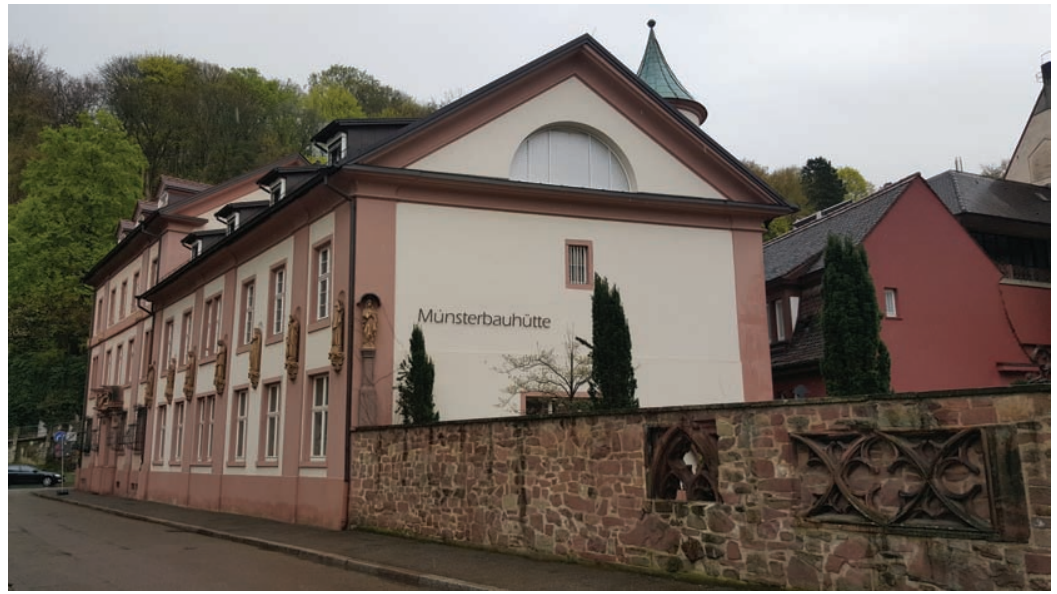

Figure 1. Freiburg Muensterbauhuette (photograph by author)

imperatives or a belief in the modern. The emphasis is generally on function - the load/traffic capacity of a structure rather than a consideration of its societal or engineering significance. It is debatable whether this situation has changed over 250 years and, indeed, whether the modern engineering profession with all its advanced technological aids is better placed to make sound decisions about the built environment than Smeaton and Telford.

There are many engineering publications and events illustrating improved 'tools', but will they mean that the engineering profession of the future is seen as one of philistines or rounded professionals arguing for the conservation of the built environment and capable of making broader decision-making beyond their technical sphere to ensure that smart engineering solutions are not dictated by short-term austerity economics? Generally, conservation priorities are based on age, aesthetics and big names, rather than an understanding of engineering significance. One could argue that this reflects societal appreciation, but if engineers do not create their own narrative of significance, masterpieces will crumble. Perhaps engineers prefer an easy life, but if they have to deal with heritage legislation and pressure groups, surely it would be better if they can argue the case for engineering significance rather than content themselves with limited technical advice and facade retention work.

\section{History and precedent embedded in early practice}

In the formative years of the British civil engineering profession in the eighteenth century, with formal engineering education unavailable and engineering literature largely absent, early engineers actively sought out precedents, collected what literature was available, kept memoranda books and undertook study tours (Skempton, 1996). Thus, Smeaton visited the Low Countries, Rennie travelled around Britain and Telford toured both southern Scotland and the West Midlands early in their careers. The hardwon self-education of these early masters underpinned the British emphasis on practical experience as a significant element of the formation of engineers which persists.
However, rather more was expected than learning on the job. From the start, it was recognised that the professional needed qualities and knowledge beyond technical expertise. Perhaps the first definition of these qualities was provided by John Farey c. 1810.

In the comprehensive article 'Canals', Farey, having extolled the significance of canals in the economic development of a country, notes (Farey, 1820)

When it is proposed to form any canal, the choice of a skilful and experienced engineer is an object of primary consideration. Without due attention to this object, many impracticable projects may be adopted, and large sums of money may be expended without accomplishing any important and useful purpose.

Farey (1820) went on to describe the qualifications of an engineer

A Skilful Engineer should undoubtedly possess a degree of mathematical knowledge. Calculations, of which some are of the most obtuse and laborious kind, will frequently occur, and he should, therefore, be well acquainted with the principles on which all calculations are founded, and by which they are to be rightly applied in practice. An Engineer should also have studied the elements of most or all of the sciences, immediately connected with his profession; and he should particularly excel in an acquaintance with the various branches of mechanics, both theoretical and practical. His knowledge should comprehend whatever has been written or done by other engineers, and he should have information in every department of his office from an accurate examination of the most considerable works that have been executed in all the various circumstances that are likely to occur. It is necessary, that he should be a ready and correct, if not a finished, draughtsman. He should also be conversant with the general principles of trade and commerce; with the various operations and improvements in agriculture; with the interests and connection of the different occupiers of land, houses, mills, etc.; and with all the general laws and decisions of courts, pertaining to the objects associated with his profession. By an extensive acquaintance with ... the various strata 
Engineering History and Heritage

Volume 169 Issue EH4
Engineers and conservation: two

centuries and no progress?

Chrimes
... which compose the soil or land of the British islands, he will be able to avoid many errors incident to those who are destitute of this knowledge.... As to the last, though not the least of these qualifications of an engineer ... we should add, that he should be a man of strict integrity. If, at this day, the affairs of any canal company should be entrusted to persons deficient in all or the greater part of the qualifications above enumerated, the managers of such a company will thus incur a serious responsibility to the proprietors and to the public.

One can see that many of these qualities might be associated with a liberal education. However, there is clearly an expectation that the professional would be familiar with the works of others and precedents.

Seventy years later, Benjamin Baker, while mindful of the value of engineering theory, emphasised the need for engineers to observe the actual behaviour of structures (Baker, 1881)

He must protest, however, against the charge implied against him of a contempt of theory. His habit of thought and mode of working were entirely opposed to such a feeling, and, indeed, in his opinion, an engineer who did not attempt to classify his practical data with the ultimate aim of elucidating a satisfactory theory was wilfully playing the part of a blind man. An engineer, however, must not be content with merely seeing a thing, but must approach it and handle it; and he thought that if theorists had to do the same they would often find that things were vastly different to what they appeared at first glance or from a more remote distance.

Baker's formative experience was in ironworks and on the construction of the Metropolitan line. From the latter, he distinguished " "the actual lateral pressure of earthwork" ... from what may be termed the "textbook" pressures, which, with hardly an exception known to the author, are based on calculations that disregard the most vital elements existent in fact'.

One might therefore expect that from the start the profession would be regarded as one with great understanding of the behaviour of existing structures and respect for its heritage.

\section{Reversible, replicable, invisible}

The almost commonplace inherent understanding by early engineers of existing structures can be illustrated by the typical if relatively unknown Trubshaw family. James Trubshaw $\mathrm{Sr}$ (1746-1808), county surveyor in Straffordshire from 1792, was a son and grandson of a mason. In 1795 many of the county bridges were swept away or damaged by flood, and Trubshaw was involved in the repair of many of them. His son James Trubshaw Jr (1777-1853) worked on this job. Likewise trained as a mason, he left home for London as a teenager, returning in the 1790 s before moving to Stone, where he set up in business as a building contractor. He took on his father's business on the latter's death and built the Grosvenor Bridge over the River Dee at Chester, designing the cantering. Trubshaw's status was reflected in his election to the ICE in 1827. In 1832, the magistrates at Shrewsbury sought his opinion on the problems of the Welsh Bridge. He also undertook repairs to Knypersley reservoir, on the Trent and Mersey canal, and became its engineer.

However, Trubshaw's best-known repair work, as shown in Figure 2, was to right the tower of Wybunbury Church (Anon, 1834); 96 feet $(29.3 \mathrm{~m})$ high and built partly on soft sandstone

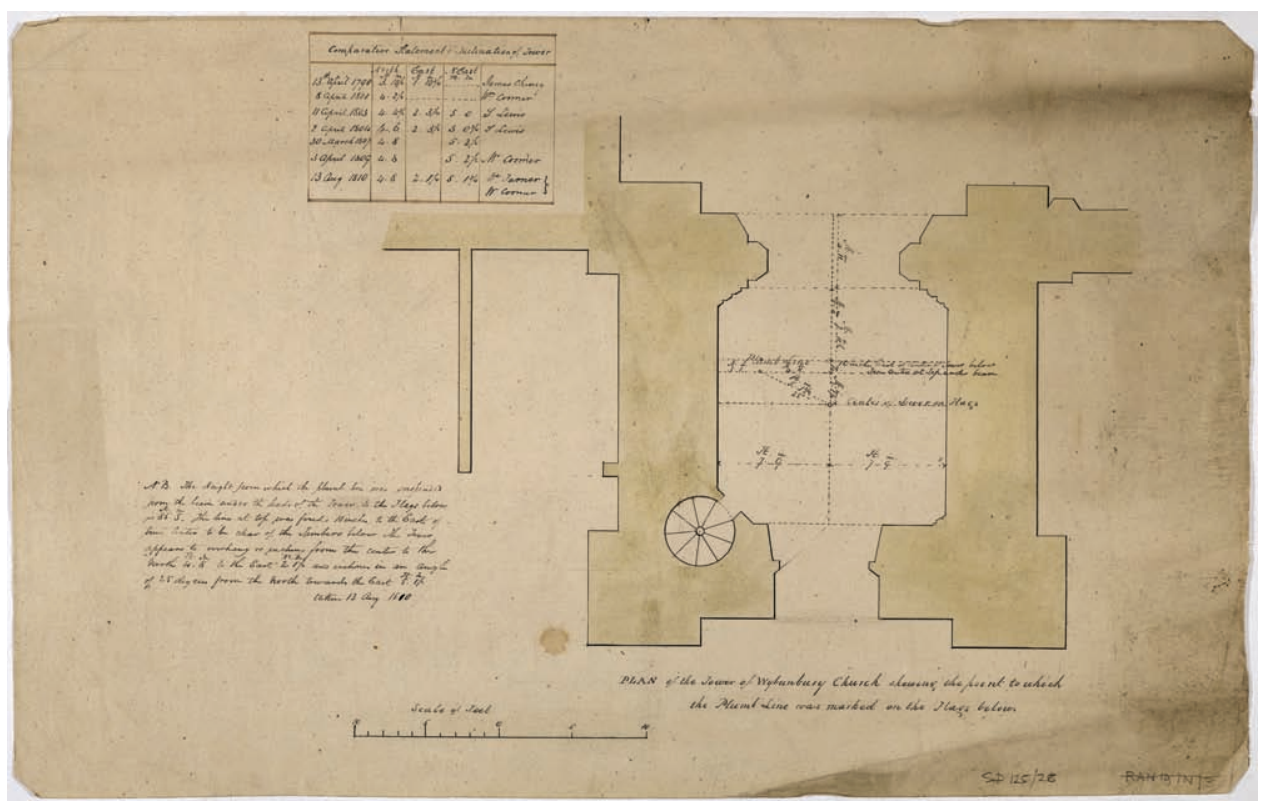

Figure 2. Trubshaw's plan of Wybunbury Church tower (Royal Institute of British Architects drawings collection) 
and partly on clay, it had developed a lean of more than 5 feet $(1.56 \mathrm{~m})$, due to brine extraction in the strata below and creep of the adjacent hillside. By digging a trench within the tower and boring a series of augur holes from it under the footings of the tower on the high side, which were filled with water to soften the ground overnight, material was removed in small stages until the tower regained the perpendicular. Cracks in the steeple closed and were rendered imperceptible. Trubshaw also introduced an inverted arch to help stabilise the foundations. He then demolished and rebuilt the body of the church to his own design; a subsequent rebuilding has now also been removed, leaving the tower freestanding. This work acquired renewed interest when the successful stabilisation work was carried out at Pisa in the 1990s. It was regarded as consistent with modern conservation practice - repeatable, reversible and invisible (Johnston and Burland, 2004).

Pisa must therefore be regarded as an example of engineers using a traditional technique (underexcavation) in the context of modern computer analysis and monitoring techniques to save a building of international significance (Mibac, 2006). In 1990 a committee was appointed by the Italian government, concerned by the increased rate of inclination. The auguries were not good, as a number of previous committees had failed to agree on a solution and some well-respected advisors were determined on more obtrusive, probably fatally damaging, structural interventions. Time was bought by the use of unsightly lead weights to help slow the movement of the tower, and underexcavation was carefully modelled, trialled and monitored before it began in earnest. The precedent was in Mexico City rather than the Cheshire salt fields (Burland et al., 2009; Tamaz et al., 1997).

Trubshaw was also a successful railway contractor, and his career must have been typical of many mason engineers. Most were eclipsed by the achievements of ICE's first president.

\section{Telford: mason, architect, infrastructure engineer}

Thomas Telford, like the Trubshaws, trained as a mason and concentrated his early efforts at self-improvement on architecture. It was not until his late twenties, while working in Portsmouth on the dockyard commissioner's house and chapel that he broadened his experience into general civil engineering by observing harbour and dock work under construction and by studying limes and mortars. On completion of the dockyard buildings, in 1786, Telford went to Shropshire to undertake the restoration of Shrewsbury Castle. Soon afterwards he became county surveyor of public works, with responsibility for public buildings and the provision of at least 42 bridges (Cross-Rudkin, 2007). During and after restoration of the castle in the Gothic style, Telford practised as an architect. His church work included building the new churches of St Mary Magdalen, Bridgnorth, St Michael and Madeley and planning the church of St Leonard, in Malinslee. It also involved the restoration of the churches of St Mary, Shrewsbury and All Saints, in Baschurch (Penfold, 1980).
In 1788 at patron Pulteney's request, Telford advised on the church of St Chad, in Shrewsbury, accurately predicting its fall just before the actual event. The cause for calling him in was a leaking roof, but he realised grave digging had undermined the walls, particularly the north-west support of the tower. The church vestry was dismissive (Telford and Rickman, 1838: p. 26)

These fractures were said to be there from time immemorial - and it was said by even sensible people that Professional men always wish'd to carve out employment for themselves and that the whole might be done at a small expense which they proceeded to do.

Although the church vestry employed a stonemason, it was without Telford's supervision. He arrived for work as the church bell struck, bringing the tower down into the nave. 'The very parts I had pointed out gave way and tumbled down, the mighty mass forming a very remarkable ruin' (Gibb, 1935: p. 15).

Thus, by his early thirties, Telford was well ensconced in the master mason tradition of designing both new works and maintaining and, in some cases, stabilising existing structures. His heritage credentials are reinforced by his work at Wroxeter (Turner, 2008). Here he superintended the excavation of the ruins of the Roman city of Uriconium, on Pulteney's estate, the plan and sections for which are his earliest known published drawings (Figure 3) (Telford, 1789, cited by Leighton, 1789). The considerable extent of his knowledge of historical precedents is indicated by the content of his substantial articles in the Edinburgh Encyclopaedia, 'Bridges', 'Civil architecture' and 'Inland navigation' (Brewster, 1830).

However, as engineer for St Katharine docks, Telford faced a dilemma which confronts most modern infrastructure engineers. The first major dock schemes in London of around 1800 were mostly carried out in largely undeveloped land to the east and south east of the city. Despite ongoing improvements in the 1820 s, there was still a demand for further development. Some merchants were dissatisfied with the charges levied by the main companies, who all operated under some form of privilege. With the end of the West India docks' monopoly in 1823, the situation was reviewed by a parliamentary committee on trade, which recommended an end to privileges. The passage of the Warehousing of Goods Act 1823 (1823) served as the necessary catalyst, and in 1824 the St Katharine docks bill was promoted with Telford as the engineer (Chrimes, 2007).

St Katharine's precinct, in the shadow of the tower and close to the city of London, had been identified as a potential dock site in the 1790 s, but no action had been taken - perhaps because its potential dock acreage was so small - although a small creek dock already existed adjoining the Hospital of St Katharine. The area was densely populated, as shown on the outline drawings of the docks. The presence of the Norman hospital foundation in particular aroused concern about the impact of demolition of the area, but a satisfactory settlement with the trustees paved the way 


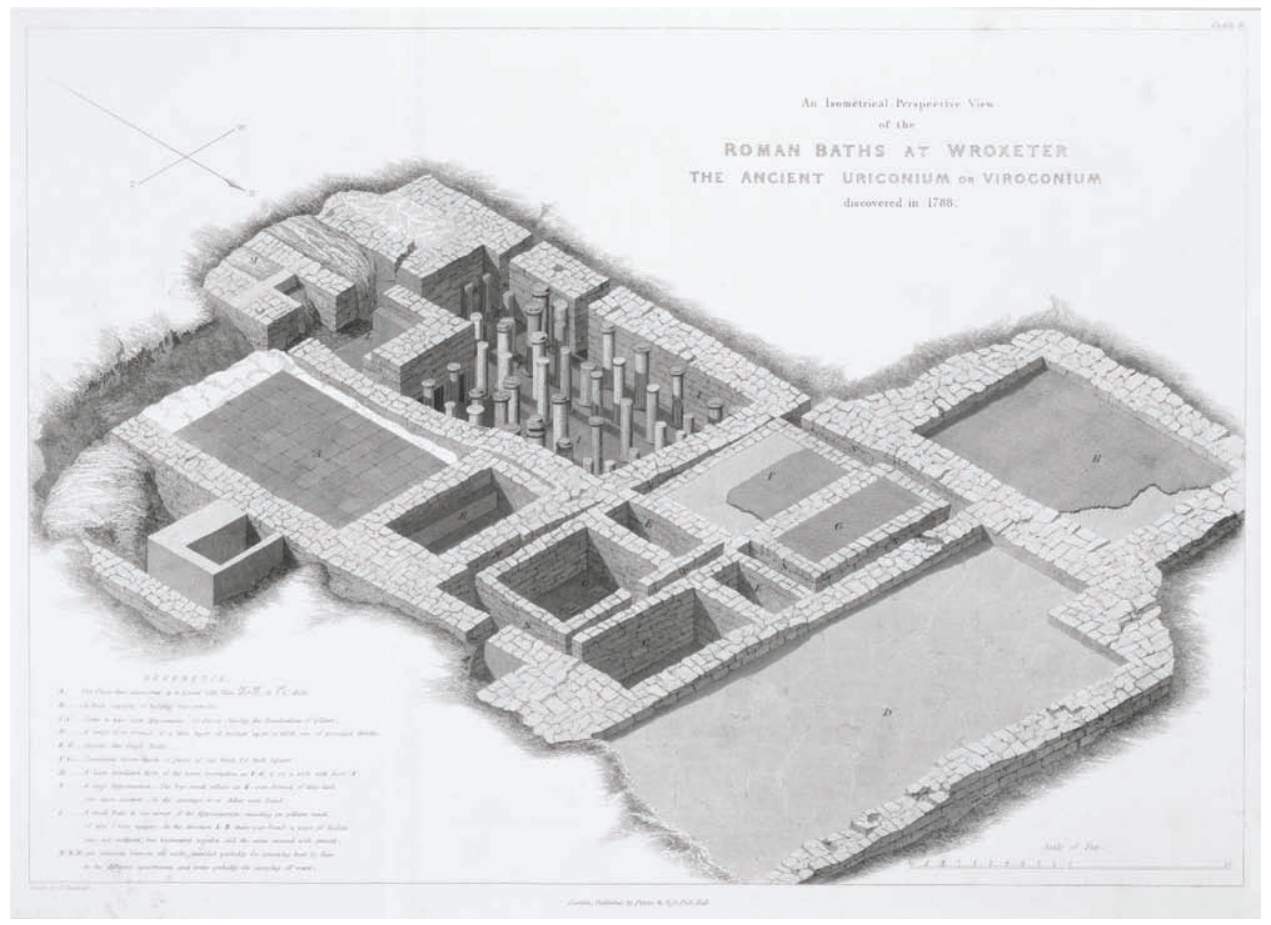

Figure 3. Telford's plan of Uriconium (ICE Library)

for the promoters' success in obtaining an act in 1825. The cost of this, and compensation to a brewery and the landlords of 1100 mostly insanitary dwellings, made the site among the most costly acquisitions involved in the dock construction of the period. It was, of course, property owners whose interests the promoters had to satisfy, and their tenants had little recourse. In this case, opposition was most vocal from the London docks, who were the closest neighbours and competitors, immediately to the east, rather than the well-compensated hospital and landowners.

\section{Railway engineers as vandals}

This was a pattern to be repeated in many cities in the railway age, as despite the cost of urban property, the major railway companies were able to level working class housing and barge through historic monuments as long as compensation could be paid. The London and Blackwall railway and the Midland railway extension in London barged through working class areas (Hunter and Thorne, 1990). Railways might be hidden from the views of the stately homes, but in places such as Newcastle upon Tyne and Conwy, the existing historic fabric was paid scant attention, with the results still visible today. One can soon build a case for the engineer as the vanguard of the Victorian philistine, or 'the designer of more effective abrasives for grinding the noses of the poor' (Jarvis, 1996: p. xvii).

The cracking above the railway tunnel in Conwy's city walls (Figure 4) does provide, however, an opportunity to consider how engineering practice has advanced. Underpinning and other stabilisation techniques were available at the time, but prediction and compensation works are another matter. The construction of the first underground railways in London provided a wealth of practical experience and commercial drivers to find engineering solutions. Cracking of building affected by railway works brought heritage arguments to the fore in the case of St Paul's Cathedral and an opportunity for Benjamin Baker to reassure the nation.

On the Metropolitan and Metropolitan District railways, much work was in cut and cover or in shallow-depth tunnels, with much disruption to surface traffic and some cracking in neighbouring buildings. On the City and South London line, much was still in doubt. Lift access to deep-level tubes was an innovation. Brick construction was used in places where experience then proved cast iron linings were preferable to minimise subsidence.

Much was made of the potential damage to structures above the central line. Baker (1890) remarked

I am certain that the whole amount of damage to property on the [Metropolitan and District] Railway from beginning to end has now been as much as that which would occur from an ordinary fire which you would see described in 'The Times' in about six lines. The benefits from the construction of the Underground Railway, of course, are incalculable.

Baker (1890) displayed an almost arrogance when speaking of the likelihood of damage to St Paul's

I have been carrying out railways past important buildings within 2 feet, 3 feet, and under buildings, and now, suddenly after 30 years' experience, I am told I cannot go within $300 \mathrm{ft}$ of a building.... We are 
Engineers and conservation: two

centuries and no progress?

Chrimes

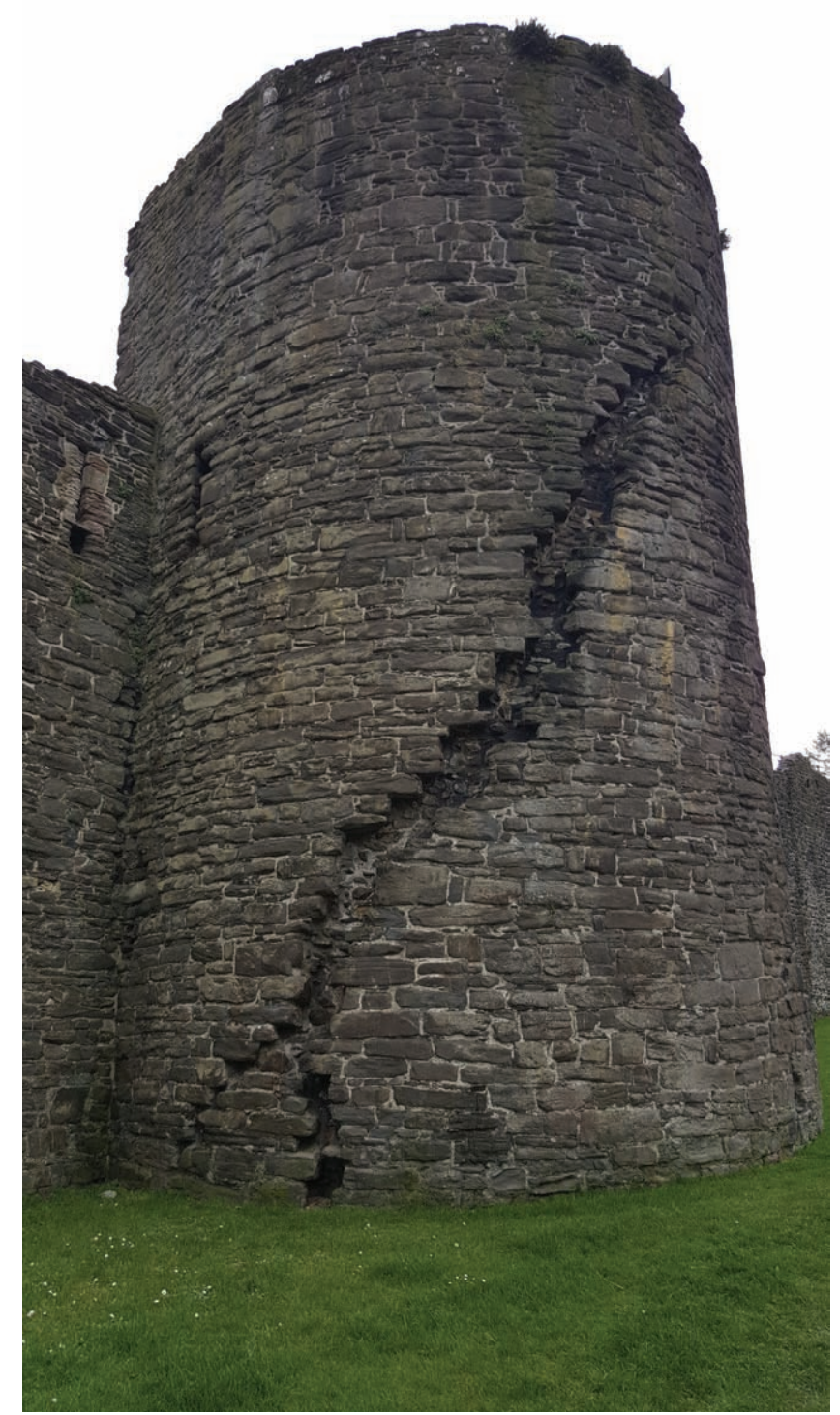

Figure 4. Conwy town wall, 2016 (photograph by author)

such a distance from St Paul's that if we were to make our railway in open cutting, like the Great Northern or the North Western ... we should still have space enough between the top of the head of our cutting and St Paul's Cathedral to build another cathedral of the same size, on the flat ground left.... I made a model to see what would happen in the events of every precaution being neglected, and I will take such a wild suggestion as this: that the contractors did not put in the iron lining of the tunnel, or they tried to deceive the engineers by painting the clay with red lead to that it might appear lined with iron. I made a model to see what would happen then. I drew my tunnel out of the soil of these spherical balls (of dried peas and sand), and what happened was there was a depression extending from where the tunnel was at a slope of about a half to one from the surface.... If a street is of a width equal to the depth of the tunnel below the surface, then the collapse of the tunnel would, according to my experience in actually carrying out tunnels, and in this model also not crack the building, it would not disturb the ground if the width of the street is equal to or greater than the depth of the tunnel.

It is of some note that 30 years later there was a great, largely unfounded, panic about the structural condition of St Paul's, yet Baker's views in the 1890 s seem to have been unchallenged. The extent of the care being taken by engineers in the 1890 s is illustrated by the underpinning work at St Mary's Woolnoth - for which Baker and Basil Mott were the engineers (Perkins, 1920). This Hawksmoor church in the city was located above the proposed terminus of the extended city and South London railway (Figure 5). The diocese were unwilling to sanction demolition, and the building was underpinned with new foundations permitting the driving of tunnels 110 feet $(33.5 \mathrm{~m})$ below.

Work involved removing the floor and much of the internal fittings, installing four steel box girders (Figure 6) 57 feet (17.4 m) long set on steel legs to extend on stanchions to a steel grid and plates on a 3 feet $(0.914 \mathrm{~m})$ deep concrete foundation below. The girders were arranged in pairs and laid longitudinally alongside the existing foundation piers; steel needle girders were installed crossways through the existing columns and saddling the box girders, and the load of the existing building was transferred to this network of girders and needles. Extensive use of grouting was made to consolidate the existing masonry and integrate the old and new structures. In the end a church structure estimated to weigh $1300 \mathrm{t}$ was supported on a network of seven main girders.

In Baker can also be seen an early example of a leading engineer with both respect for the achievements of past generations of engineers and willingness to argue the case for conservation when others were happy to see them swept away. He was called on to report on existing bridges showing signs of distress, most famously three of Telford's bridges, Buildwas, Menai and Over Bridge, Gloucester. His efforts to save Buildwas ultimately proved fruitless; at Menai the strengthened bridge served until Alexander Gibb carried out work between the wars. At Over Bridge (Gloucester) where '... certain barbarians were actually urging the magistrate to take down the bridge' (Baker, 1888), he successfully underpinned it. 'He told the magistrates it would be a disgrace to the country if they pulled down Telford's historical works' (Baker, 1888). The bridge had suffered from subsidence, to Telford's chagrin, since its first construction due to insufficient foundations beneath the abutment wing walls (Baker, 1888; Heyman and Threlfall, 1972).

Baker's respect for his predecessors was accompanied by a strong sense for the aesthetics of engineering structures. He crossed swords with William Morris over the appearance of the Forth Bridge. 'Probably Mr Morris would judge the beauty of a design from the same standpoint, whether it was for a bridge a mile long or for a silver chimney ornament. It was impossible for anyone to pronounce authoritatively on the beauty of an object without knowing its functions' (Baker, 1889). In the case of the Forth Bridge, '[t]he object had been so to arrange the leading lines of the structure as to 


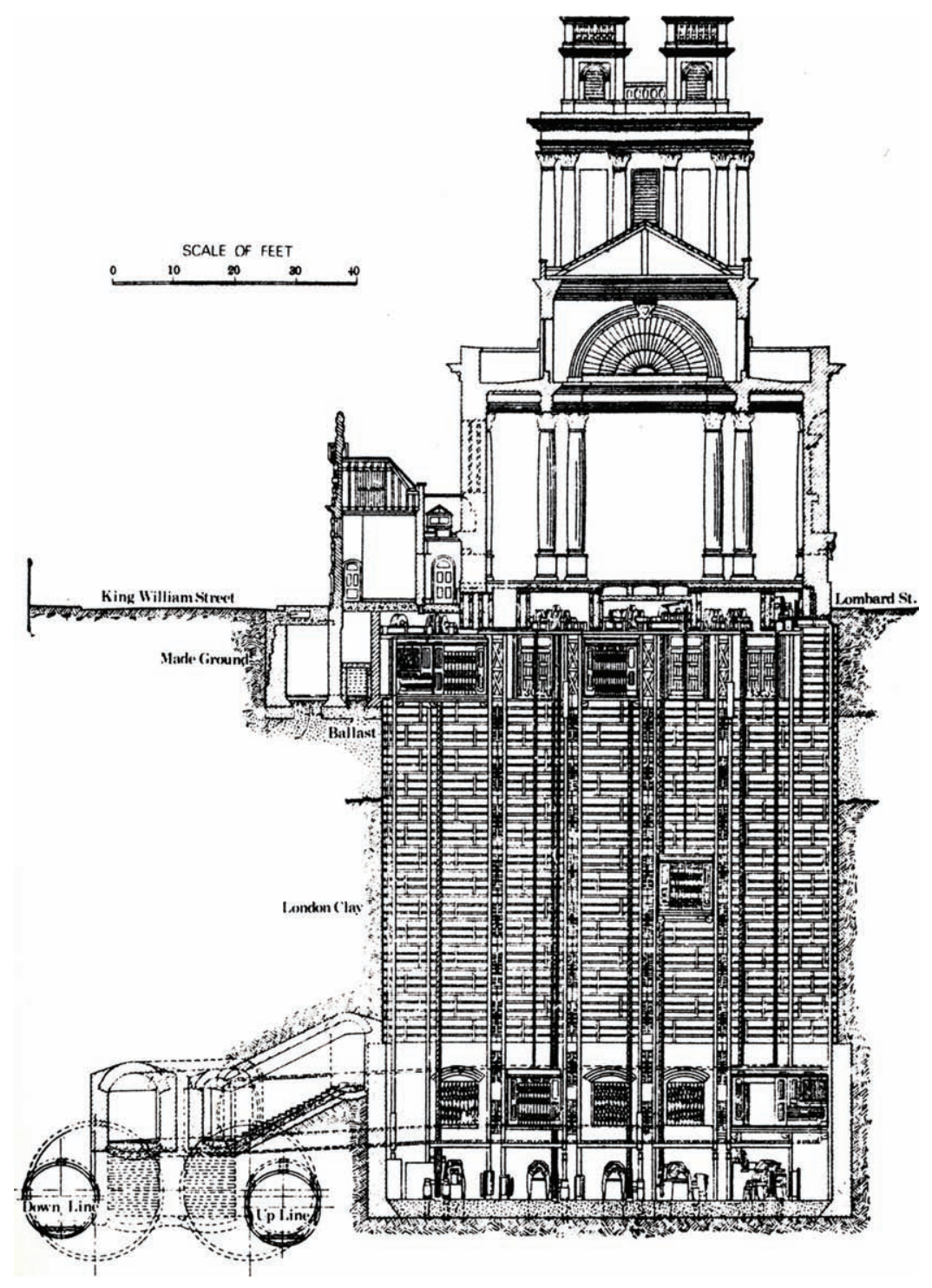

Figure 5. Cross-section of Bank station beneath St Mary Woolnoth

convey an idea of strength and stability. This, in such a structure, seemed to be at once the finest and highest art' (Baker, 1889).

\section{Early heritage engineers}

Baker's contemporaries Douglas and Francis Fox also had extensive experience of tunnelling and railway engineering (Fox, 1924). They worked closely with Greathead as consultants to London's Great Northern and City railway in 1892, and then they designed the Charing Cross, Golders Green and Highgate railway. Francis Fox (Figure 7) saw the potential of the grouting pan, devised by Greathead for tunnelling works, for other applications and became involved in the use of grouting in the restoration of historic structures (F. Fox's papers, 1880-1920, ICE Archives). The most famous application was at Winchester Cathedral, where Fox was appointed consultant in 1905. The masonry was in poor condition, and this was compounded by the effects of subsidence.
Fox advised the strengthening of the masonry, making use of grouting equipment, and then underpinning of the foundations with concrete. As the excavations rapidly filled with water, Fox had to use diving equipment to undertake his inspections. Consequently, the initial underground work was carried out by a diver, William Walker, who, working largely by touch in dark, peaty water for over five and a half years, sealed the excavation bases, thereby enabling underpinning to be carried out in drier conditions (Bussby, 1974). The work, widely reported as one of the engineering wonders of the age, was completed in 1912.

Fox was consulted over many other ancient buildings, such as Peterborough Cathedral (1897), St Paul's Cathedral (1912), Lincoln Cathedral (1921-1924) and Canterbury and Exeter Cathedrals. Outside the UK, Fox reported on St Sophia in Constantinople, Turkey, and on the campanile of St Mark's, Venice, Italy. While 
Engineers and conservation: two centuries and no progress?

Chrimes

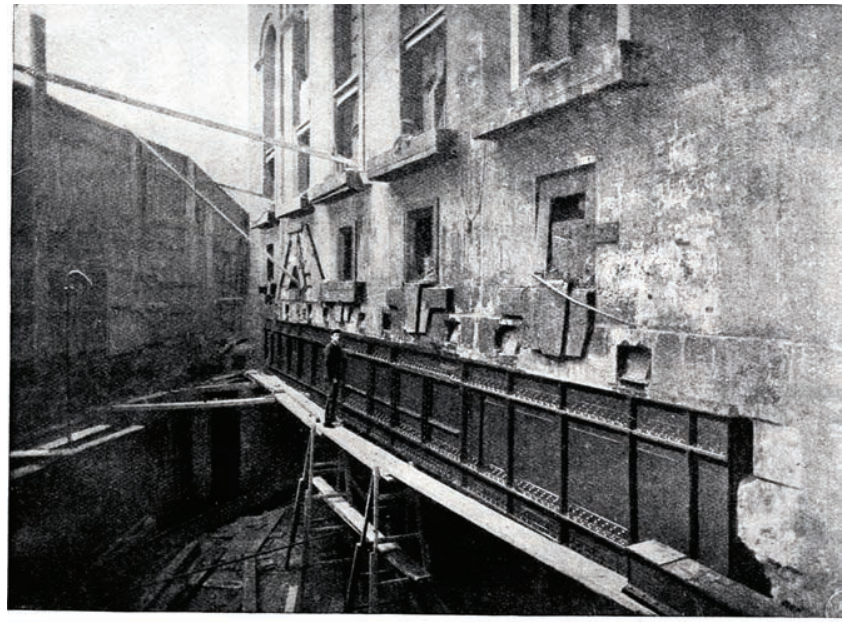

ST. MARY WOOLNOTH-OUTSIDE GIRDER IN POSITION FOR SUPPORTING SOUTH WALL OF CHURCH, PACING KING WHLIAK GTRERT.

Figure 6. Photograph of St Mary Woolnoth outside girders beneath south wall (Mott Macdonald Archive, ICE)

some of his work might be regarded unfavourably by modern conservationists, it demonstrated that engineers had a role to play in conserving the historic built environment, an area normally considered the preserve of architects, although the great architects of the Victorian era frequently took liberties with the medieval heritage they advised on.

\section{The Victorian architect as structural conservationist}

The best-known example of a Victorian conservation architect is probably Sir George Gilbert Scott (1811-1878) (Scott, 1879). Many of his relations, including his father, were Anglican clergymen, and it was through the patronage of the established Church that Scott was able to build up a massive practice. His early training included a spell with the building contractors Grissell and Peto, constructing the Hungerford market designed by Charles Fowler 'on principles then new', as Scott (1879) later noted, 'Iron girders, Yorkshire landings, roofs and platforms of tiles in cement, and columns of granite being its leading elements'. He was attracted by the Gothic revival, and by the 1840 s, churchbuilding and restoration became his chief source of work, at which he proved skilled if ultimately a controversial figure.

In 1847 he was appointed to his first cathedral, Ely. Westminster Abbey followed in 1849, and by the time of his death, there were only a few English cathedrals or major religious buildings where he had not worked. He overcame major structural challenges at St Albans, St David's and Salisbury. He built on his experience and used careful underpinning techniques in combination with shoring and strapping and often deep new concrete foundations and structural cement grouting. He was called in at Chichester Cathedral, where the central tower collapsed in 1861 (Figure 8) while work was being undertaken by the engineer Thomas Yarrow, whose experience was largely as a railway engineer and

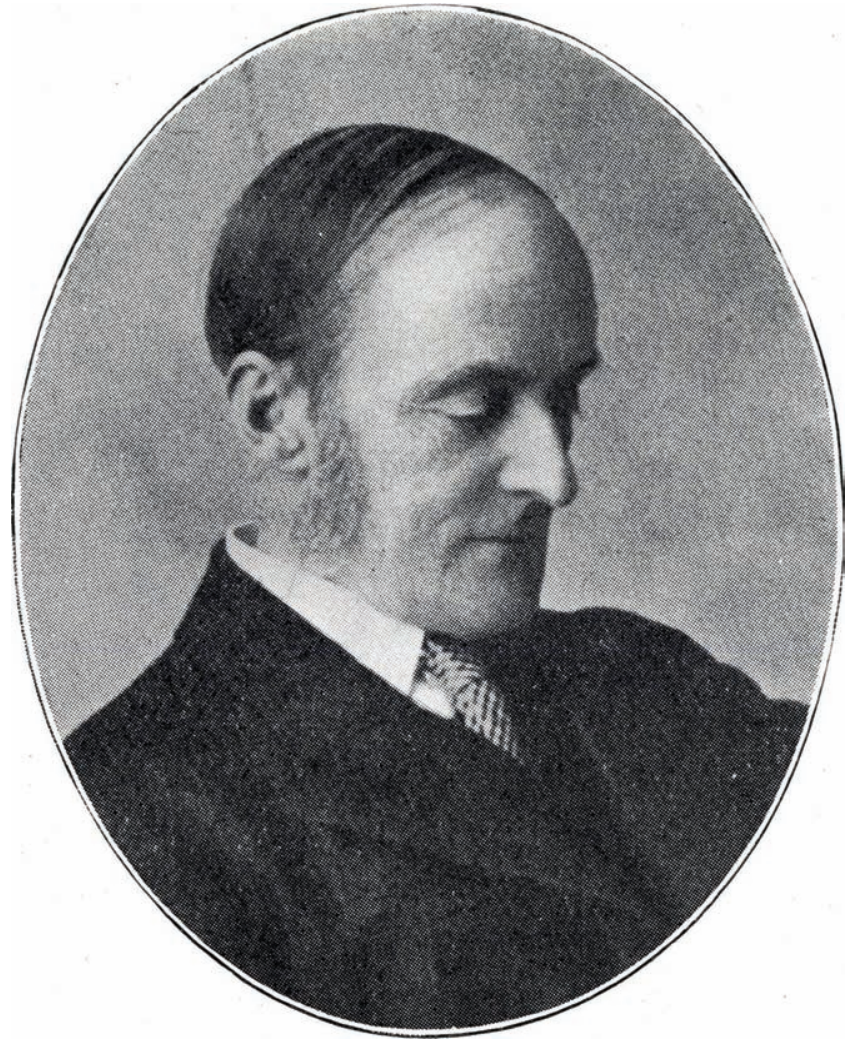

Figure 7. Francis Fox (ICE Library)

county bridge surveyor (Willis, 1861). Scott rebuilt it to the original design, raised by several feet. His most remarkable effort was at St Albans, where he rescued the crossing tower and used hydraulic jacks to right the upper south wall of the nave.

Towards the end of his career, his methods were being challenged by William Morris and the infant Society for the Protection of Ancient Buildings, who saw him as the obvious scapegoat for the damage done they saw being done to old churches by Victorian architects. He defended himself rigorously. Neither Scott nor the Society cared about authenticity of the structure behind the scenes. Provided masonry surfaces and mediaeval styles were respected, radical restorers and conservative repairers of churches alike availed themselves of modern technologies.

Scott used hidden iron liberally in his restoration work, as he did in his mainstream secular architecture. He was probably aware of the work by George Gwilt Jr at Southwark Cathedral in the early 1820s. John Burlison (1810-1868), for many years his chief assistant, was said in to have united with antiquarian knowledge 'the constructive science of the engineer', but where more expertise was required, he turned to engineers. His first known collaborator was F. W. Sheilds, who worked on Crystal Palace and designed the framework of the Albert Memorial. Sheilds went on in 1865 to report on strengthening Salisbury Cathedral's crossing tower and to install an elaborate system of vertical and 


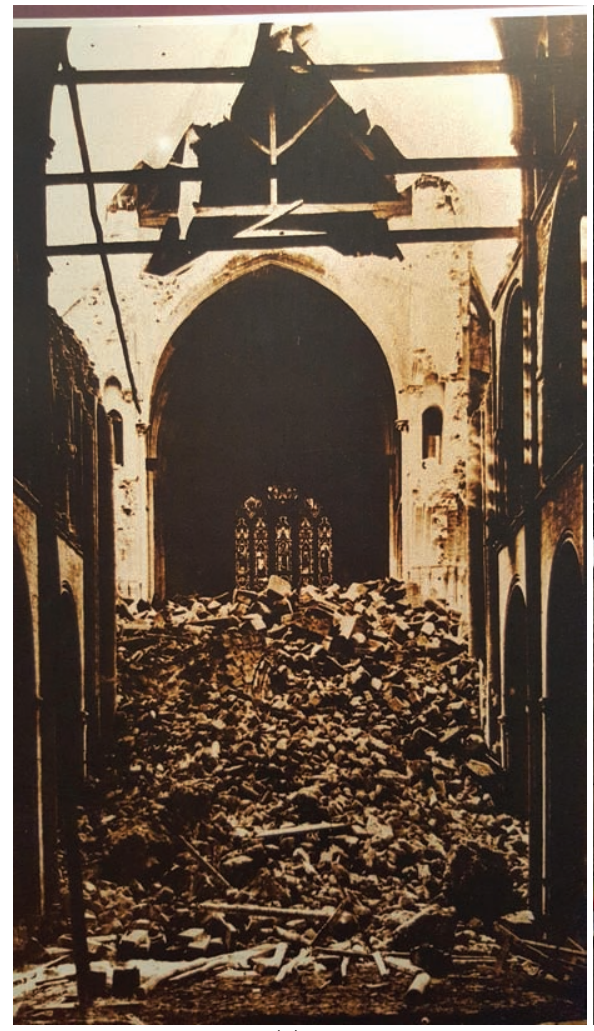

(a)

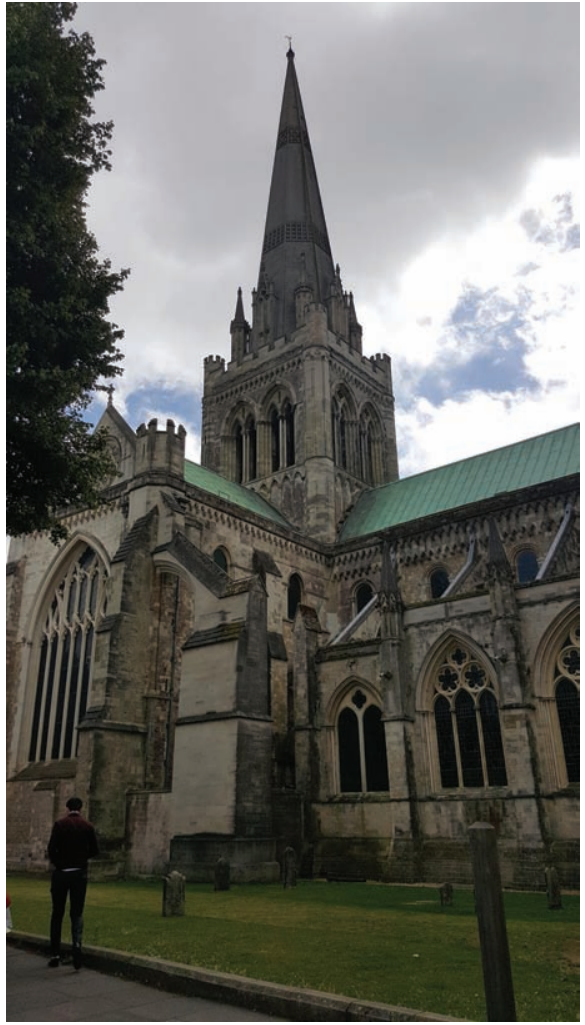

(b)

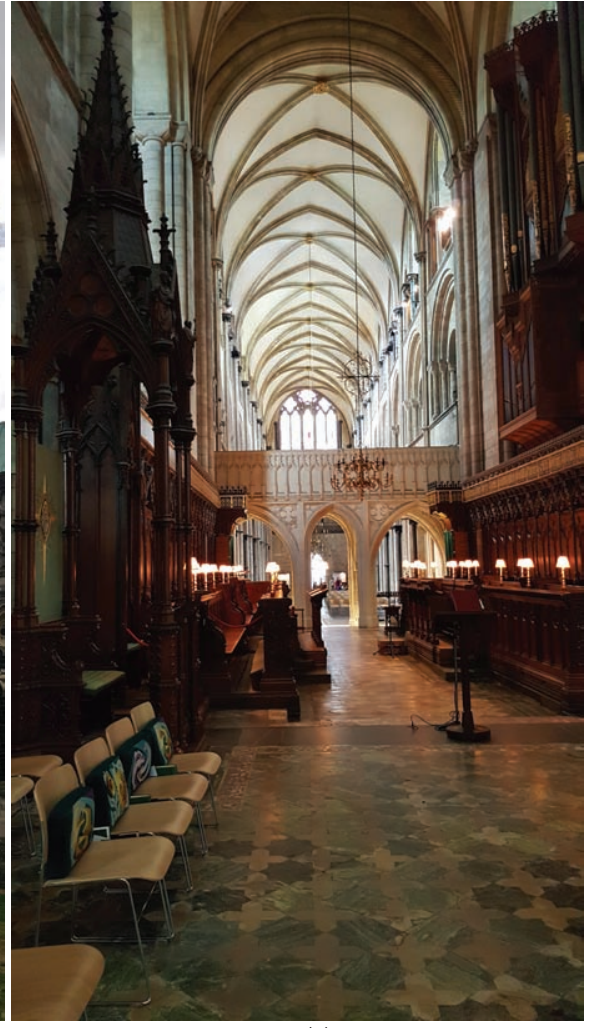

(c)

Figure 8. (a) Chichester Cathedral after the central tower collapsed in 1861; (b) exterior of Chichester Cathedral, 2016 (photograph by author); (c) interior of Chichester Cathedral, 2016 (photograph by author)

diagonal iron ties, after which Scott's masons repaired the stonework (Cotta, 2008). At Westminster Abbey Chapter House and the Leeds Infirmary, the consultant was R. M. Ordish. The latter's obituary claimed that Scott consulted him 'on all important questions of structure'. It has been suggested that Sheilds's work was the first formal consultation of an engineer on a cathedral restoration, although this was not the case; it is an indication that a skilled architect recognised the need for a structural engineer's advice on technical issues (Saint, 2007).

\section{Engineers as conservation architects in India}

While architects generally undertook structural restorations of buildings in the Victorian period, in the Raj, the engineer was the leading professional and several were detailed to undertake restoration work and/or busied themselves in learning the building and architectural practice of the subcontinent (Chrimes, 2015, 2016). Colonel John Theopilus Boileau (1805-1886), born in Calcutta, India, was trained at Addiscombe from 1819 and returned to India as an ensign in 1822 . He carried out a number of repairs to Mughal sites around Agra and Futtrepore, including the Taj Mahal, where the cost of scaffolding - £120 - led to suspension of the work.
From the mid-nineteenth century, far greater attention was being paid to Indian precedents in developing colonial architecture. As an example, one might consider Robert Fellowes Chisholm (1838-1915), who was for a period a government architect for the Madras Presidency. He was the son of a Scottish-born artist and successfully applied for a position as a civil engineer in the Public Works Department around 1860. By 1865 he was the officiating executive engineer at Patna, capital of Bihar, leading a team that included six junior engineers. He then won an architectural commission and argued that what he described as the Mussulman style should become the model for new imperial architecture. The greatest change in his style came with the commission to restore the Tirumalai Nayak Mahal in Madurai, where, among other measures, he used wrought-iron ties to stabilise the dome.

Other examples of engineers making the transition to competent architects inspired by the heritage they found in India include Henry Irwin, Swinton Jacob and Colonel Charles Mant.

\section{Twentieth century's challenges}

In the second half of the twentieth century, new challenges faced the civil engineering profession as the infrastructure heritage for which they were custodians required updating or became obsolescent. 
Waterloo Bridge, the masterpiece of John Rennie, suffering from subsidence, was demolished at the advent of the Second World War in part at the insistence of the client, the London County Council (LCC) (as seen in Rendel Palmer \& Tritton collection, ICE archives). By 1945, canals and much of the railway network were losing traffic to the roads, which desperately need updating. In general, the waterways became clogged up, and then, spearheaded by the Inland Waterways Association, enthusiasts brought pressure to bear to maintain and later reopen the network for leisure use. However, road engineers frequently placed problems in the way of canal conservationists by constructing bridges at a level which effectively precluded the reopening of sections of navigations without incurring additional costs. Similar decisions were made following the many rail closures of the Beeching era.

\section{The Euston Arch (Anon, 1962; Smithson and Smithson, 1968)}

British Railways (BR) faced difficult decisions, as there was still a demand for its services, but public funding was limited. There was a great desire to modernise, and many of its buildings became difficult to justify. Matters came to a head with conservationists over the future of Euston station, which was a chaotic assemblage of buildings put up over a century as rail traffic grew and ill suited as the gateway to the introduction of fast electrified services to the north.

However, the London and Birmingham railway was the greatest engineering achievement of the early Railway Age and its 'monuments' deserve to be venerated as such. The Euston saga is a testament to the state of planning law and conservation in the late 1950s. Little was made of the overall significance of the engineering monuments on the line, yet there was recognition of the Euston Arch and Great Hall as important architectural monuments - they had been two of the largest buildings in London when erected. As BR developed its plans, there was no real thought given to a development plan that treated the existing fabric with respect rather than isolated museum artefacts. At the time, despite the fact there were a number of representations to preserve the Euston Arch, there was no responsible body to act. The railway, then as now, was cash strapped by the government, and no plan would carry the costs of preservation. No thought was given to the historical significance of the iron roof (Figure 9). The engineering consultants who advised the LCC recommended demolition of the Great Hall and re-erection of the Doric Arch.

Given the 'Euston clutter' of the time, one could question whether the result would be different today. Today's station is threatened by the advent of HS2, and the simple approach of 1960s' engineers and architects has been despoiled by the pursuit of commercial income, which has introduced a twenty-first-century clutter to rival that of the 1930s. Ironically, HS2 has also revived interest in recreation of the Euston Arch (Euston Arch Trust, 2016).

\section{Engineering against architecture}

The Euston story is regarded as key in the revival in interest in and respect for the Victorian built environment. However, there

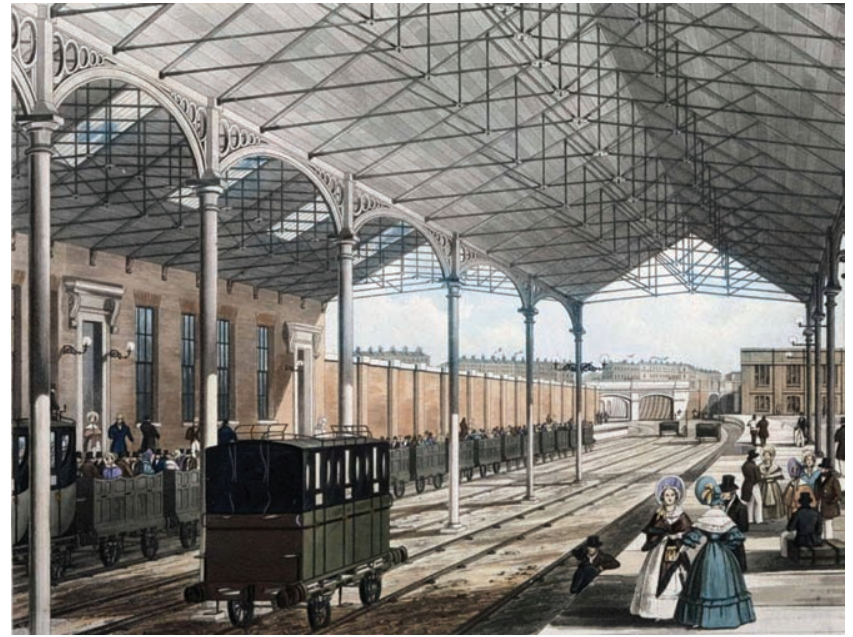

Figure 9. Euston station roof (source: Osborne's London and Birmingham Railway Guide (Anon, 1840))

remain significant barriers in the maintenance of engineering heritage. Where the visual aesthetic is not regarded as significant, statutory protection is difficult to obtain. Thus, masonry bridges and tunnel portals may be listed and interior structures and tunnels themselves may be ignored, although they may be the most significant achievement. Attractive masonry spillways may be listed, but earth embankments are ignored. There is also a hierarchy of engineers, with emphasis on the designer rather than the builder, and a fashion for I. K. Brunel and general ignorance of, for example, the Stephensons and Locke and the later engineers, with Sir John Hawkshaw being notably unknown. Bazalgette is a household name, but Newlands in Liverpool is virtually forgotten. It might be easy to blame the largely architectural professionals staffing the various national bodies responsible for heritage, but the engineering profession itself is rarely better informed. For several years, span 4 of the roof at Paddington station suffered Brunel blight as senior figures at Railtrack/Network Rail considered how to improve Paddington station and the potential commercial yield of the site (Wilkinson et al., 2006). It was hidden from view, although, as now displayed, it is one of a piece with the remainder of the station clearly designed to fit in with the original Brunel roof when the station was extensively remodelled around a century ago. It would seem that because it was not part of the original Brunel design, some surmised that it could be dispensed with in some air rights or similar development. This view paid scant respect to the Great Western railway (GWR) engineers who carried out major works on a scale similar to Brunel himself in modernising the late Victorian and Edwardian network and indeed had dismantled the Brunel roof and installed a 'modern' replica.

\section{Thames tunnel}

One could argue that the Thames tunnel story is one that offers more hope for satisfactory conservation and treatment of significant engineering works without evident aesthetic appeal. It 
Engineering History and Heritage

Volume 169 Issue EH4
Engineers and conservation: two centuries and no progress?

Chrimes has long been acknowledged as one of the landmark civil engineering structures in the British Isles. It was recognised as such by the ICE's second president, James Walker, as long ago as 1847 when he wrote

I have often said and thought that it is the greatest engineering work in this country, on account of its final success after so many accidents, and the means that were taken to overcome them.

Its engineering significance is manifold - the first modern subaqueous transport tunnel in the world and the first example of the use of a tunnelling shield in soft ground. Either would qualify it for landmark status, but it is the problems which Sir Marc Isambard Brunel had to overcome which have seized the imagination of modern commentators as much as Walker and his contemporaries and given it a greater significance than an engineering 'first'.

In 1993 the American Society of Civil Engineers jointly with the ICE affixed a plaque denoting the Thomas tunnel an 'international civil engineering landmark', at a time when its future was in doubt. London Underground or the equivalent client to Transport for London at the time was concerned about the vulnerability of the tunnel to flooding, largely as a result of heightened awareness of terrorism. It was immediately apparent the tunnel had unsatisfactory statutory protection to ensure a sympathetic strengthening that would enable the tunnel to be properly recorded and part at least to be restored (Figure 10). A high-level panel of experts involving ICE and International Tunneling Association past president Sir Alan Muir Wood; Dr Francis Walley, the leading UK expert on blast effects on structures; the industrial archaeologist Dr Denis Smith; and consulting engineer James Sutherland provided advice and challenged the assumptions of London Underground Limited's (LUL) consultants.
The controversy revealed a lack of knowledge about Brunel's design assumptions regarding the tunnel's structure and the strength of brickwork and mortars of the time, although Brunel's detailed investigative approach is well known. Those able to visit the tunnel saw the drainage system exposed, and this raised questions about how the system was designed, how it was intended to work and even when it was installed - during construction or after completion. While much attention had been paid to the engineering of the tunnel down to the completion of the bore, little has been done on its subsequent service life. Muir Wood and Skempton in consequent papers highlighted the engineering achievement of the tunnel and described the methods by which it was achieved (Muir Wood et al., 1994; Skempton and Chrimes, 1994). These papers were of much value to LUL's engineers as well as the conservationists who campaigned for listing and conserving the works (Roach, 1998).

However, despite this landmark listing, only a few tunnels have statutory protection beyond their portals and recording their engineering construction and achievement remains a specialist enthusiasm of the tunnelling industry.

\section{Ordsall chord (Anon, 2016a; Network Rail, 2016)}

The controversy over the Ordsall chord - the alignment of a link between Piccadilly and Victoria stations in Manchester in the vicinity of the original Liverpool Road station terminus of the world's first modern intercity railway between Liverpool and Manchester - provides a recent example of how future infrastructure needs require difficult decisions for civil engineers. Here past ICE president Mark Whitby was so concerned by Network Rail's proposals that he resigned as consultant to Parsons Brinkerhoff, who had involved him in their work on the

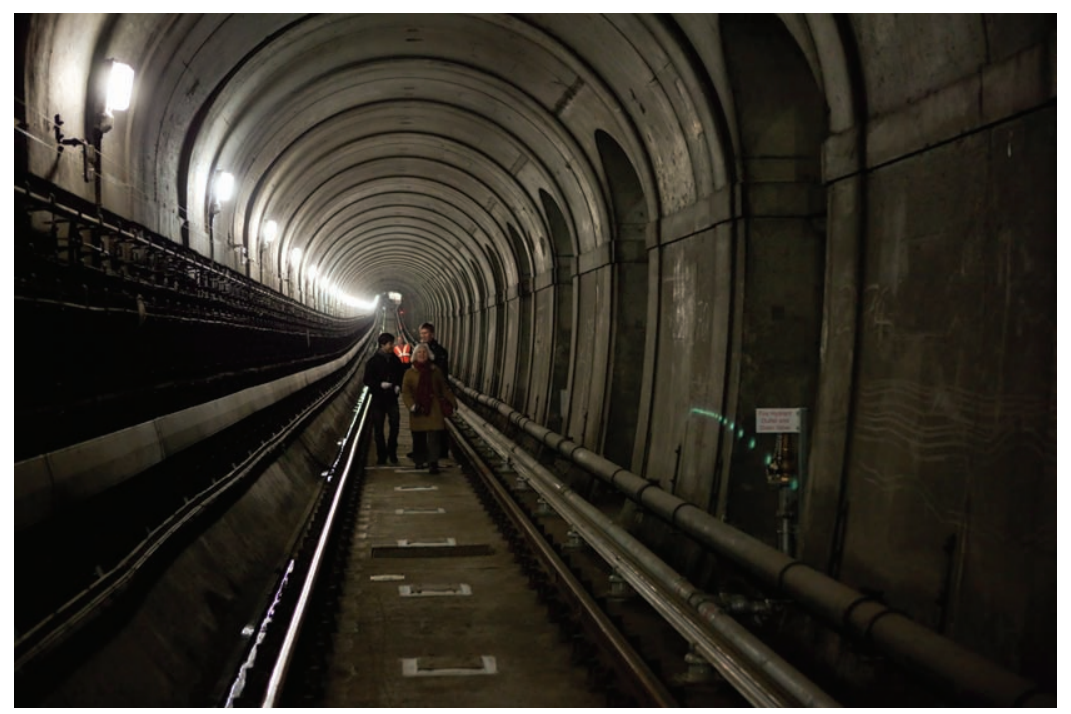

Figure 10. Thames tunnel walk (source: Lars Ploughman (Wikimedia, 2010)) 
Northern Hub. In his view, another alignment was possible that would involve less damage to the historic fabric. Although unsuccessful at the original April 2014 inquiry, he financed two further appeals. The inspector considered 'an element of hyperbole which has crept into the objectors' case. This is not a world heritage site and comparisons with Stonehenge and the Pyramids are not helpful' (Anon, 2016a). Others' views may differ; if such comparisons are not made, how does one obtain a critical appreciation of key monuments of modern history in comparison with the relics of prehistoric times?

Certainly Network Rail's original proposal, modified following discussions with, among others, ICE Panel for Historical Engineering Works (Phew) chair Brian Crossley, involved damage to Jesse Hartley's original 1830 Irwell Railway Bridge (Figure 11), and Network Rail apparently failed to engage with English Heritage about their proposals affecting a number of heritage structures at an early stage. There is a suspicion that Network Rail and its advisors saw the opportunities of additional funding without prior consideration of their own heritage. A consequent 2-year delay ensued. In contrast, work on the GWR main line and Midland main line seems to have been progressed with full consultation with English Heritage/Historic England (English Heritage, 2013; Kinchin-Smith, 2014a, 2014b, 2016). It is noticeable that Historic England seems to be concentrating on goods stations and other representative redundant buildings rather than load-bearing civil engineering works as their priority for conservation. Certainly, a large number of bridge structures have been modified or removed on the GWR lines (Anon, 2016b).

\section{The need to study engineering history}

There are a number of reasons for the engineering profession to study history

- obtaining an understanding of how the engineering profession operates today - and some reasons why it differs from the profession in continental Europe
- understanding how methods of analysis and design in use today have been developed, which can provide insight into possible limitations on their application and also into how structures were designed in the past

- understanding how structures and works were constructed in the past and providing an insight for those involved in their maintenance and refurbishment, as well as presenting a range of traditional materials and techniques with which they might otherwise be unfamiliar

- studying projects of the past for an insight into management, project organisation and control, risk and forensic engineering

- developing research skills which can be widely applied through a professional career

- ensuring that information on the history of engineering is as readily available to the media and general public as other 'histories' and that the profession to a degree owns its own story

- ensuring that engineers are able to compete on an equal footing with architects and conservationists for work involving historical sites.

Many younger engineers will believe that with the power of the analytical and monitoring tools at their disposal, their need to understand the history of a structure is minimal. But as Baker said, 'a string of formulae do not make an engineer'.

\section{What is an important structure?}

One problem that has been persistently exposed by the work of ICE Phew is assessing the significance of an engineering structure, identifying what is significant about it and. as perhaps indicated by the Ordsall hub inspector, the invidious comparison with other monuments of different 'classes'. In a somewhat notorious example from the 1970 s, the then technical secretary of the panel was dismissive of the significance of the Bennerley viaduct, regarding it as only of local significance. However, this view is dependent on how it is classified and, as seen even more starkly with seaside piers, survival.

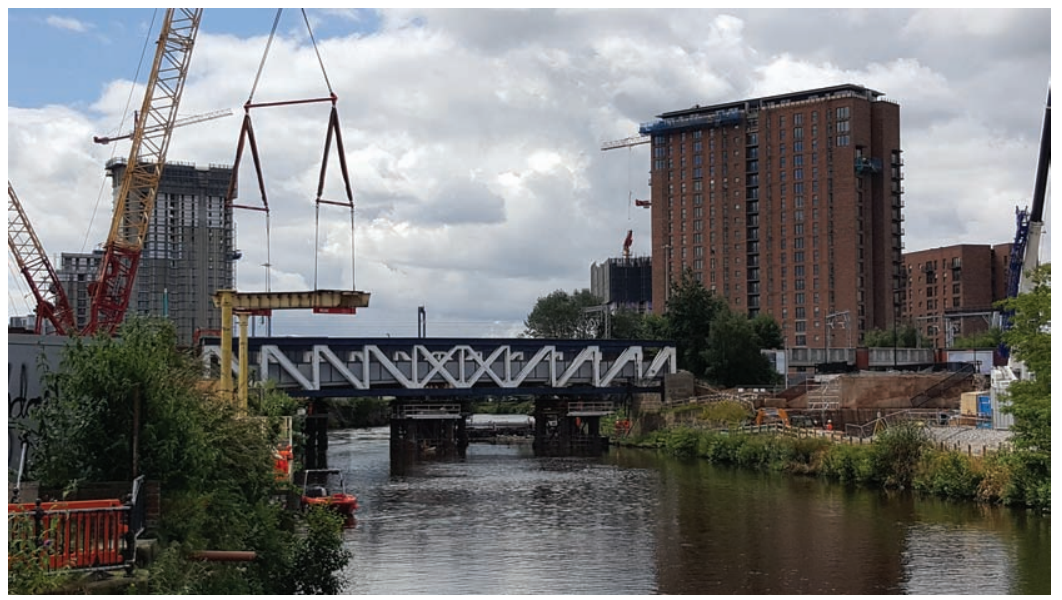

Figure 11. Ordsall chord works, July 2016 (photograph by author) 
Engineering History and Heritage

Volume 169 Issue EH4
Engineers and conservation: two

centuries and no progress?

Chrimes
Such issues led Phew to undertake thematic investigations into 'piers', 'bridges', 'water towers', 'mills', 'dry docks' and so on to try and establish a framework for assessment. In some areas, the basic listing did not exist on which to hang a frame. For water towers, over 1000 sites were identified of public water supply towers and a further 400 of other ownership. When work began, there were 161 on which no additional data could be found other than the site. The height was known in only $24 \%$ of the cases, the date in $47 \%$, the designer and contractor only in $6 \%$ and the capacity in $52 \%$. In the absence of readily available data on so many structures, extensive research is clearly necessary before a comprehensive database can be constructed, yet without it how can sound judgements on the historical significance of an individual structure be depended on? In its deliberations, the Panel determined a number of properties that could be looked at to enable comparative assessment and refined according to the type of engineering work (Cross-Rudkin et al., 2000).

One might assume that one of this country's most significant structures, the Union Suspension Bridge over the Tweed (Figure 12), at the time of its construction the longest-span level, deck suspension bridge in the world and today the oldest suspension bridge in the world carrying road traffic, would be one whose future was secure. Designed by Samuel Brown with Telford, the most important early British designer of bridges of this type, its future is in doubt because of the cost of repairs and strengthening. Surely, this structure should be championed by the profession, and, certainly, its engineers are aware of its significance; they just need the funding. Hopefully, the bridges' friends can ensure its survival.

Elsewhere good conservation practice has eluded some - the 'strengthening' of Gattonside Suspension Bridge in 1991-1992 was so misguided that it left the original chains amidst 'a jumble of ponderous steelwork' (Ruddock, 1999). Grampian Regional Council, misled by the calculations of its engineering advisors, was about to replace the cast iron arch of the Carron (former Railway) Bridge over the Spey with steel ribs in 1993 until the analysis was challenged. On further investigation, the bridge was proved safe without modification (Swailes, 2006). Over the past 25 years, award schemes such as the ICE Scotland's Saltire Awards, the ICE Phew/EH/BWB/NR/CSS Historic Bridge and Infrastructure Awards and the Institution of Structural Engineers have rewarded good conservation practice (Masterton, 2016).

With many older engineering structures, one also has the old broom syndrome. What remains of the original? Has repair and strengthening work undermined the historical significance of the structure? Seaside piers can provide a strange conglomerate of materials and structural elements effectively undermining the simplicity of the original as seen at Eastbourne in 2014 (Figure 13), but enabling the sense of place to endure.

Bridge strengthening at Menai and on the great suspension bridges of the 1960s can generally be regarded as respectful and necessary, but other examples can be found where unnecessary and unsightly strengthening continues to take place. Modifications to railway structures associated with electrification have puzzled some, while some contractors such as Balfour Beatty have striven hard to develop techniques to minimise the impact of electrical clearances (Balfour Beatty Rail, 2014). Changed perception of risk has driven some modifications - such as reconstruction of bridge parapets to reduce the possibility of road traffic invading rail space (Department for Transport, 2012).

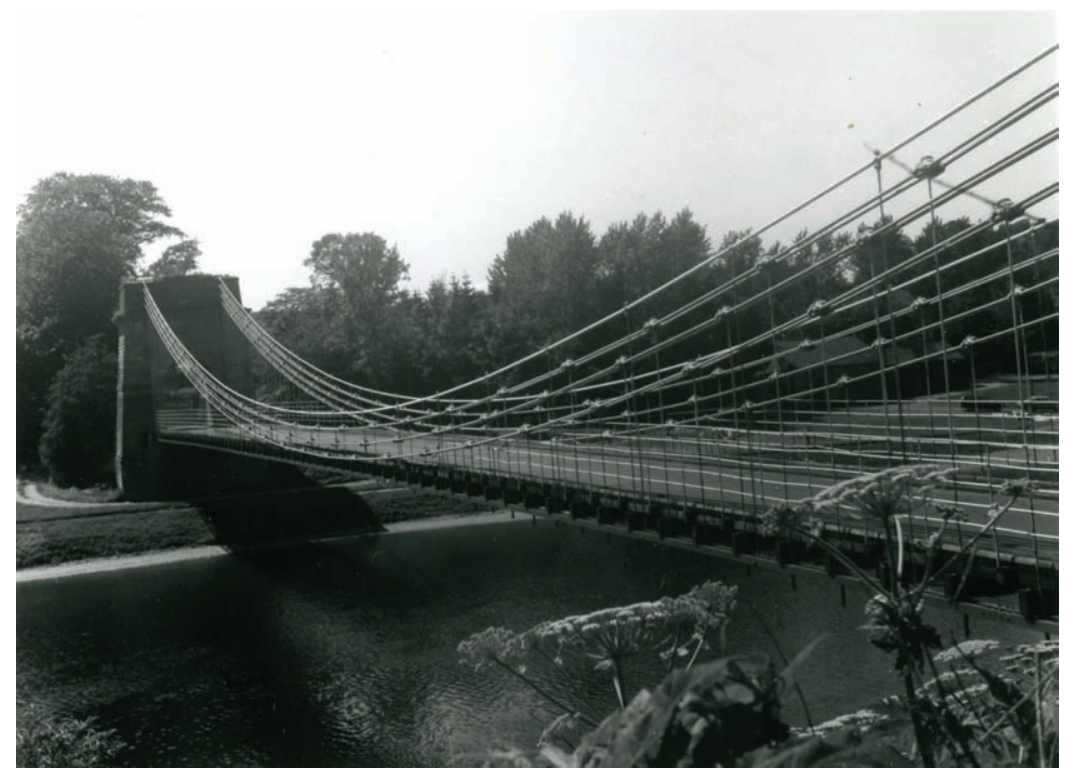

Figure 12. Union Suspension Bridge (ICE Library) 


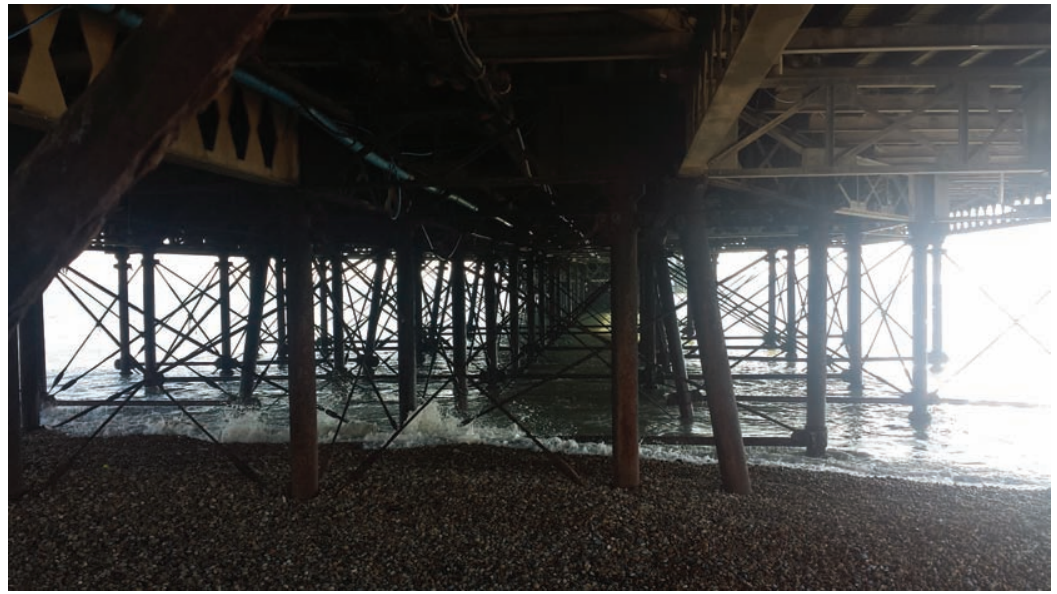

Figure 13. Underside of Eastbourne pier, April 2014, before fire damage later that year (photograph by author)

\section{Conclusion}

Many of the issues raised here are well rehearsed (Cossons, 2012; Pugsley et al., 1974, 1975; Sutherland, 1994). It is as easy for engineers today as it was 200 years ago to be regarded as the villains of the piece in their treatment of the historic built environment. The tools which have enabled Crossrail and much of the Jubilee line to be bored beneath London with little impact on historic structures such as Big Ben and St Paul's can enable this generation of engineers to redeem their reputation by persuading their clients of their ability to provide sensitive new or renewed infrastructure (Black, 2014, 2015; Burland et al., 2001). Often this will involve expenditure that may arouse concerns with clients, but a profession well informed about the historic significance of the structures they are involved with will provide the best solutions for society. Major infrastructure asset owners need to build in their training programmes an awareness of the historical engineering significance of the works in their care and good conservation principles. Infrastructure is not just about function; it shapes society's sense of place, and it is a testament to its original creators' vision. Engineers should show love and respect for the works in their care through an understanding of the professionals of the past. Hero worship of the Brunels and Bazalgette needs to be extended more broadly. If the original vision is sufficiently compelling, complete reconstruction should be considered, in particular where the original materials - frequently the case with reinforced concrete - were poorly executed. Such an approach may create its own problems when it may apparently involve the destruction of modern buildings and the recreation of a bygone era.

\section{Acknowledgements}

This paper is based on a presentation at the International Association for Bridge and Structural Engineering British Group's Henderson Colloquium, Cambridge, UK, July 2016.

\section{REFERENCES}

Addis W (2007) Building: 3000 Years of Design Engineering and Construction. Phaidon, London, UK.
Anon (1834) Domestic notices - England. Architectural Magazine, vol. 1, p. 209.

Anon (1840) Osborne's London and Birmingham Railway Guide. Osborne W. \& E.C., Birmingham, UK.

Anon (1962) The Euston murder. Architectural Review, April. Anon (2016a) Ordsall chord. Rail Engineer, 25 March.

See http://www.railengineer.uk/2016/03/25/ordsall-chordvandalism-or-progress/ (accessed 22/09/2016).

Anon (2016b) Severn tunnel electrification. Modern Railways, August: pp. 70-75.

Baker B (1881) Actual lateral pressure of earthwork. Minutes of the Proceedings of the Institution of Civil Engineers 65(1881): 140-241, http://dx.doi.org/10.16 80/imotp.1881.22268.

Baker B (1888) Discussion on Hooghly Bridge. Minutes of the Proceedings of the Institution of Civil Engineers 92: 115-116.

Baker B (1889) Lecture at the Edinburgh Literary Institute, 27 November.

Baker B (1890) Minutes of Evidence on the Central London Railway Bill. Central London Railway, London, UK.

Balfour Beatty Rail (2014) Electrification Clearance Solutions. Balfour Beatty Rail, Atlanta, GA, USA.

Black M, Dodge C and Lawrence U (eds) (2014) Crossrail Project: Infrastructure Design and Construction. ICE Publishing, London, UK, vol. 1.

Black M, Dodge C and Lawrence U (eds) (2015) Crossrail Project: Infrastructure Design and Construction. ICE Publishing, London, UK, vol. 2.

Brewster D (ed.) (1830) Edinburgh Encyclopaedia. William Blackwood and Sons, Edinburgh, UK.

Brooks NP et al. (eds) (1994) Traffic and Politics: the Construction and Management of Rochester Bridge AD 43-1993. Boydell Press, Woodbridge, UK.

Burland JB, Standing JR, Jardine FM et al. (eds) (2001) Building Response to Tunnelling - Case Studies from the Construction 
Engineering History and Heritage

Volume 169 Issue EH4
Engineers and conservation: two

centuries and no progress?

Chrimes of the Jubilee Line Extension. Ciria Special Publication Series, Ciria, London, UK, vol. 200.

Burland JB et al. (2009) Leaning tower of Pisa: behaviour after stabilization operations. International Journal of Engineering Case Histories 1(3): 156-169.

Bussby F (1974) William Walker: the Diver Who Saved Winchester Cathedral. Friends of Winchester Cathedral, Winchester, UK.

Chrimes MM (1989) The Institution of Civil Engineers' Library and archives: a brief introduction. Construction History 5: 59-66.

Chrimes MM (2001) Archives and resources for historical engineering structures: the historical treasures of the Institution of Civil Engineers, London. In International Engineering History and Heritage, Proceedings of the 3rd National Congress on Civil Engineering History and Heritage, Houston, 2001 (Rogers JR and Fredrich FJ (eds)). American Society of Civil Engineers, Washington, DC, USA, pp. 113-122.

Chrimes MM (2007) St Katharine Docks, London - Telford's high-speed harbour. Proceedings of the Institution of Civil Engineers - Civil Engineering 16(5): 48-55, http://dx.doi.org/ 10.1680/cien.2007.160.5.48.

Chrimes MM (2015) Architectural dilettantes: construction professionals in British India 1600-1910: Part 1. 1600-1860: the age of the dilettante. Construction History 30(2): 15-44.

Chrimes MM (2016) Architectural dilettantes: construction professionals in British India 1600-1910: Part 2. 1860-1910: the advent of the professional. Construction History 31(1): 99-140.

Cossons N (2012) Does the engineering heritage matter? Proceedings of the Institution of Civil Engineers Engineering History and Heritage 165(4): 211-219, http://dx. doi.org/10.1680/ehah.11.00023.

Cotta RS (2008) Engineering survival and success: the contributions of historic structural features in the spire and tower of Salisbury Cathedral. In Structural Analysis of Historic Construction (D'Ayala D and Fodde E (eds)). Taylor \& Francis, London, UK.

Cross-Rudkin PSM (2007) Thomas Telford, county surveyor. Proceedings of the Institution of Civil Engineers - Civil Engineering 160(5): 7-11, http://dx.doi.org/10.1680/cien.2007. 160.5.7.

Cross-Rudkin PSM, Cragg R, Dunkerley P, Gould MH and Otter RA (2000) The assessment of civil engineering heritage. Proceedings of the Institution of Civil Engineers - Municipal Engineer 139(4): 211-216, http://dx.doi.org/10.1680/muen. 2000.139.4.211.

Department for Transport (2012) Guidance on the Design Assessment and Strengthening of Masonry Parapets on Highway Structures. Department for Transport, London, UK. See http://www.ukroadsliaisongroup.org/en/utilities/documentsummary.cfm?docid=43F6D2D7-DCE3-4F8DAE64A1D33AC6CAC3 (accessed 22/09/2016).

English Heritage (2013) Midland Main Line Consultation. English Heritage, Swindon, UK. See http://www.englishheritage.org.uk/caring/listing/listed-buildings/consultationprocess/midland-main-line-designation-consultation/ (accessed 01/07/2016).
Euston Arch Trust (2016) http://www.eustonarch.org/ (accessed 22/09/2016).

Farey J (1820) Canals. Cyclopedia (Rees A). Rees, London, UK. Fox F (1924) Sixty-three Years of Engineering. London, UK. Gibb A (1935) The Story of Telford. Maclehouse, London, UK. Hallom HE (1965) Settlement and Society. Cambridge University Press, Cambridge, UK.

Harvey J (1971) The Master Builders. Thames \& Hudson, London, UK.

Heyman J and Threlfall BD (1972) Two masonry bridges: II. Telford's bridge at Over. Proceedings of the Institution of Civil Engineers 52(3): 319-330, http://dx.doi.org/10.1680/iicep. 1972.5294.

Hunter M and Thorne R (1990) Change at King's Cross. Historical Publications, London, UK.

ICE (Institution of Civil Engineers) (2016) BIM and Asset Management. ICE, London, UK. See https://www.ice.org.uk/ disciplines-and-resources/best-practice/relationship-betweenbim-and-asset-management (accessed 22/09/2016).

Jarvis A (1996) The Liverpool Dock Engineers. Alan Sutton, Stroud, UK.

Johnston G and Burland J (2004) Some historic examples of underexcavation. Advances in Geotechnical Engineering: Skempton Conference, 2004, London, UK, vol. 2, pp. 1068-1079.

Kalchthaler P et al. (eds) (2014) Baustelle Gotik: Das Freiburger Muenster. Michael Imhof Verlag for Staedtische Museum and Freiburger Muensterbauverein, Freiburg, Germany (in German).

Kinchin-Smith R (2014a) National Heritage Protection Plan NHPP 4B3: Transport and Communications 4B3.102: Historic Railway Buildings and Structures: Overview of Development Pressure and Review of Significance: Volume 1: Overview of Significance and Investment Trends. Historic England, Swindon, UK. See https://historicengland.org.uk/images-books/publications/ historic-railway-buildings-and-structures/ (accessed 22/09/2016).

Kinchin-Smith R (2014b) National Heritage Protection Plan NHPP 4B3: Transport and Communications 4B3.102: Historic Railway Buildings and Structures: overview of development pressure and review of significance: Volume 2: Statements of Significance. Historic England, Swindon, UK. See https:// historicengland.org.uk/images-books/publications/historicrailway-buildings-and-structures/ (accessed 22/09/2016).

Kinchin-Smith R (2016) National Heritage Protection Plan NHPP 4B3: Transport and Communications 4B3.102: Historic Railway Buildings and Structures: overview of development pressure and review of significance: Volume 3: Maps \& Gazetteer. Historic England, Swindon, UK. See https:// historicengland.org.uk/images-books/publications/historicrailway-buildings-and-structures/ (accessed 22/09/2016).

Leighton F (1789) Memoir concerning the Roman baths discovered in the year 1788 at Wroxeter, the ancient Uriconium or Viroconiu. Archaeologia 9: 323-328.

Mair RJ et al. (eds) (2016) Through Smarter Information: Proceedings of the International Conference on Smart Infrastructure and Construction, Cambridge Centre for Smart Infrastructure in Construction. ICE Publishing, London, UK. 
Masterton GM (2016) Civil engineering heritage: country profile - Scotland. Proceedings of the Institution of Civil Engineers Engineering History and Heritage 169(3): 140-146, http://dx.doi.org/10.1680/jenhh.16.00007.

Mibac (Ministerio per I Beni e le Attiva Culturali) (2006) Torre Restituita. Bolletina d'Arte 1-3 (in Italian).

Muir Wood AM, Wood AM and Brunel MI (1994) The Thames Tunnel 1825-43: where shield tunnelling began.

Proceedings of the Institution of Civil Engineers - Civil Engineering 102(3): 130-139, http://dx.doi.org/10.1680/icien. 1994.26770.

Network Rail (2016) Ordsall Chord. Network Rail, London, UK. See http://www.networkrail.co.uk/north/Ordsall-Chord.aspx (accessed 22/09/2016).

ONS (Office National Statistics) (2016) Construction Industry Bulletin: Construction Output January-March 2016. ONS, Newport, UK. See https://www.ons.gov.uk/business industryandtrade/constructionindustry/bulletins/construction outputingreatbritain/apr2016andnewordersjantomar2016 (accessed 01/07/2016).

Penfold A (ed.) (1980) Thomas Telford, Engineer. TTL, London, UK, pp. 1-22.

Perkins WT (1920) Great underpinning achievements. In Engineering Wonders of the World: Volume III. T. Nelson and Sons, London, UK, pp. 312-320.

Pugsley A, Mainstone RJ and Sutherland RJM (1974) The relevance of history. Structural Engineer, December: 441-445

Pugsley A, Mainstone RJ and Sutherland RJM (1975) Open discussion: The relevance of history. Structural Engineer, September: 387-398.

Roach MJ (1998) The strengthening of Brunel's Thames Tunnel. Proceedings of the Institution of Civil Engineers - Transport 129(2): 106-115, http://dx.doi.org/10.1680/itran.1998.30495.

Ruddock EC (1999) Blacksmith bridges in Scotland and Ireland. Proceedings of the International Historic Bridges Conference Wheelking, West Virginia, USA, pp. 133-146.

Saint A (2007) Architect and Engineer: a Study in Sibling Rivalry. Yale University Press, New Haven, CT, USA, pp. 141.

Scott G (1879) Personal and Professional Recollections. Sampson Low, London, UK.

Skempton AW (1996) Civil Engineers and Engineering in Britain, 1600-1800. Variorum, Aldershot, UK.

Skempton AW and Chrimes M (1994) Thames Tunnel: geology, site investigation and geotechnical problems. Géotechnique 44(2): 191-216, http://dx.doi.org/10.1680/geot.1994.44.2.191.

Skempton AW, Cross-Rudkin PSM, McWilliam RC, Chrimes MM et al. (2002) Biographical Dictionary of Civil Engineers of Great Britain and Ireland - Volume 1: 1500-1830. ICE Publishing, London, UK.

Skempton AW, Cross-Rudkin PSM, McWilliam RC, Chrimes MM et al. (2008) Biographical Dictionary of Civil Wngineers of Great Britain and Ireland - Volume 2: 1830-1890. ICE Publishing, London, UK.

Skempton AW, Cross-Rudkin PSM, McWilliam RC, Chrimes MM et al. (2014) Biographical Dictionary of Civil Wngineers of
Great Britain and Ireland - Volume 3: 1890-192. ICE Publishing, London, UK.

Smithson A and Smithson P (1968) The Euston Arch and the Growth of the London, Midland and Scottish Railway. Thames \& Hudson, London, UK.

Soga K, Kwan V, Pelecanos L et al. (2015) The role of distributed sensing in understanding the engineering performance of geotechnical structures. In Geotechnical Engineering for Infrastructure and Development: Proceedings, XVI European Conference on Soil Mechanics and Geotechnical Engineering (Winter MG, Smith DM, Eldred PJL and Toll DG (eds)). ICE Publishing, London, UK, vol. 1, pp. 13-48.

Standing JR et al. (2015) Research into the effect of tunnelling on existing tunnels. In Geotechnical Engineering for Infrastructure and Development: Proceedings, XVI European Conference on Soil Mechanics and Geotechnical Engineering (Winter MG, Smith DM, Eldred PJL and Toll DG (eds)). ICE Publishing, London, UK, vol. 2, pp. 515-520.

Sutherland RJM (1994) Active engineering history - Sutherland history lecture. The Structural Engineer 72(13): 213-216.

Swailes T (2006) Guide for Practitioners - 5: Scottish Iron Structures. Historic Scotland, Edinburgh, UK. See https:// issuu.comhspubs/docs/guide-for-practicioners-5- - -scottishiron-structures (accessed 01/07/2016).

Tamaz E et al. (1997) Under-excavation of Mexico City's Metropolitan Cathedral and Sagarario Church. Proceedings of XIV ICSMFE, Hamburg, Germany 4: 2105-2126.

Telford T and Rickman J (1838) Life of Thomas Telford, Civil Engineer. Payne \& Foss, London, UK.

Turner R (2008) Thomas Telford the archaeologist. Antiquaries Journal 88: 365-375.

Van de Ven GP (ed.) (2004) Man-made Lowlands. Matrijs, Utrecht, Netherlands.

Warehousing of Goods Act (1823) Chapter 24. Her Majesty's Stationery Office. London, UK.

Wikimedia (2010) https://commons.wikimedia.org/wiki/File: Thames_Tunnel_walk.jpg (accessed 22/09/2016).

Wilkinson A, Binney M and Sutherland J (2006) Save Paddington's Span Four - This Engineering Marvel Must Stay. Save Britain's Heritage, London, UK.

Willis R (1861) On the architectural history of Chichester Cathedral. RIBA Journal 231-238.

\section{HOW CAN YOU CONTRIBUTE?}

To discuss this paper, please email up to 500 words to the editor at journals@ice.org.uk. Your contribution will be forwarded to the author(s) for a reply and, if considered appropriate by the editorial board, it will be published as discussion in a future issue of the journal.

Proceedings journals rely entirely on contributions from the civil engineering profession (and allied disciplines). Information about how to submit your paper online is available at www.icevirtuallibrary.com/page/authors, where you will also find detailed author guidelines. 